fear that I shall not be able to finish that most difficult task. But I may note that my assertion that "Marennin" contains principally iron, is based on the recent researches of Muntz and Chatin.

Spezia, Italy, October I 2.

\title{
Oxford Endowments.
}

I AM surprised that my friend Dr. Hickson, whose past residence among us lends authority to his words, should so greatly misrepresent facts as to say, in NATURE of October 3, that "the income of the [college] endowments is frittered away in the salaries of the heads, the stewards, the bursars, and the tutors of the pass-men," the fact being that these endowments do not provide the salaries of either the stewards or the tutors. It is further difficult to see how estates can be managed without bursars, and how bursars can exist without salaries; how complex institutions can work without heads, and how heads can live on nothing; and how the payments to bursars and heads - the latter at least with stipends fixed by statute--is in any way connected with " the [alleged] unfortunate competition that exists between colleges."

Christ Church, Oxford.

R. E. BAYNES.

I AM sorry that my friend Mr. Baynes should think that I have "misrepresented facts" in my article on the "Linacre Repurts." I did not state, nor did I intend to imply, that the whole of the salaries of the tutors and stewards is derived from college endowments; but surely it is true that in the majority of cases these officers are fellows of their colleges, and as such receive a substantial sum of money annually from the college endowments.

I am quite competent to understand that college estates cannot be managed without bursars, and that bursars cannot live without salaries; but the estates of the Oxford colleges could be managed by less than half the number of bursars that now exist in Oxford-provided that they were chosen carefully from among those who have had some training or experience in their profession-and a large annual income would be saved from the endowments.

As to the heads. Speaking with every respect for these august persons, I still feel that with judicious amalgamation three or possibly four heads would be sufficient to carry on the official work, they now perform, with efficiency and dignity.

I should exceedingly regret if any remarks of mine should give offence to my friends in Oxford; but I never hesitated to express my opinion there or in Cambridge, that the independence of the colleges means a fearful waste of their endowments; and until, by Act of Parliament, a suitable amalgamation of these institutions is brought about, there will be little margin left for the endowment of research and the payment of those engaged in pure scholarship.

SYDNEY J. HiCKSON.

\section{Late Leaves and Fruit.}

Here, many of the roadside lindens have cast their summer foliage, and put forth a garniture of new leaves; these are fully grown, and bear the vivid tint of spring. In this city, on the I I th inst., well-grown open-air strawberries were on sale in the fruiterers' shops. The quantity altogether amounted to severa bushels.

Worcester, October I9. J. LLOYD BOZWARD.

\section{THE CENTENARY FÊTES AT PARIS.}

$T H E$ latter part of last week has witnessed the celebration of the first centennial anniversary of the foundation of the Institut de France. Paris was certainly not at its best, as far as meteorological features were concerned ; the weather offered nothing "Queenly" or "Presidential" in its demeanour, and upon the whole was what it generally is at this time of the year-unpleasant, wet, and cold. But it hardly interfered with the proceedings and festivities, and we trust none of the generally aged guests of the Institute will be any the worse in health for their rapid visit to Paris.

A large number of foreign associates and corresponding members had promised to come; and the occasion was

such a remarkable one, that we print in full the list of acceptations. Of the Académie des Inscriptions et BellesLettres, the Associés étrangers present were MM. Ascoli, Helbig, Max Müller, Whitley Stokes; while the Correspondants present were MM. Bailly, de Beaurepaire, Blade, Blancard, Champoireau, Chevalier, Comparetti, Delattre (le Père), De Smedt, Sir John Evans, Goeje, Gomperz, de Grandmaison, Ioret, Kern, Merlet, Millardet, Naville, Radloff, Saige, Sauvaire, Windisch. In the Académie des Sciences, the Associés étrangers who attended were Lord Kelvin and Dr. Frankland ; and the Correspondants were MM. Amagat, Arloing, Bäcklund, de Baeyer, Bayet, Bergh, Bichat, Blondlot, Brioschi, Cannizaro, Considère, Crova, Engelmann, Sir Archibald Geikie, Gosselet, Grand Eury, Haller, Herrgott, Houzeau, Kovalewski, Laveran, Lépine, Lie (Sophus), Lockyer, Marès, Marion, Masters, Matheron, Oller, Pagnoul, Ramsay, Raoult, Rayet, Retzius, Sir Henry Roscoe, Sabatier, Sire, Sirodot, Stephan, Sir G. Stokes, Suess, Sylvester, Général Tillo, Treub, Vallier. In the Académie des Beaux-Arts there were the Associés étrangers, MM. Alma Tadema, Da Silva, Gevaërt, Pradilla ; and Correspondants, MM Bertrand, Biot, Civiletti, Cui, Cuypers, Dauban, Deffés, De Geymüller, Gouvy, Guffens, Israëls, Lanciani, Le Breton, Loenhoff, Marionneau, Martenot, Perrin, Ronot, Salinas, Salmson, Sgambati, de Vriendt, Waterhouse, Wauters. In the Académie des Sciences Morales et Politiques, the Associés étrangers present were MM. Carlos Calvo and Castelar ; and the Correspondants were MM. Aubertin, Babeau, Barkausen, Bodio, Caillemer, Ducrocq, Du Puynode, Ferrand, Lallemand, Lecky, Legrand, le Comte de Lucay, Molinari, Moynier, Sir F. Pollock, Polotsoff, Raffalovich, Stubbs, Villey Desmeserets, Worms.

At one time, it had been decided to choose the epoch of the centennial anniversary for the transfer of Pasteur's mortal remains from the vaults of Notre Dame to their final resting-place at the Pasteur Institute. The plan was not carried out, and it was better so. The frame of mind which is suitable for festivities is not so for a funeral, and it would not have been in good taste to mingle the one with the other. The plan was dismissed after short, but wise, reflection. The festivities were carried out in strict accordance with the announcements made, and published in NATURE.

On the first day, the 23 rd, a religious service was celebrated in Saint Germain des Près, in memory of all members of the Institute deceased since its foundation, by Monseigneur Perraud, Bishop of Autun, a member of the Académie Française, and a very distinguished writer and philosopher. It must not be thought that, even in the land of Voltaire, all men of science consider atheism as "the" proper form of philosophy. The Institute is very conservative, and whatever opinions most members may hold concerning religion and dogmas, every man has his own conception of the universe, more or less, and entertains "son petit religion à part soi," as a witty German princess put it, in her own barbarian French. This first ceremony was largely attended, although more national than international in character. The real general opening of the celebration took place the same day at 2 p.m., when the foreign associates and correspondants were received and entertained in the salon of the Institute by the members of the latter. Each invité was announced by the huissiers, and after having been introduced to the masters of the house, joined his own personal friends and acquaintances in pleasant conversation and numerous introductions to fellow-workers of every land. The masters of the house were M. Ambroise Thomas (the author of Mignon), member of the Académie des BeauxArts, and for this year President of the Institute, assisted by M M. Maspero, Marey, Léon Say, Count Delaborde. delegates of the four other Academies. The last function of the day was a general reception of all members,

NO. I 357 , VOL. 52$]$ 
associates, and correspondants by the Minister of Public Instruction. The reception-rooms of the Ministry had been very elegantly adorned for the purpose. A whole series of tapestries--from the celebrated Gobelins manufactory-illustrating Don Quichotte's life, after the pictures by Coypel, decorated the walls of a large hall which had been built for the purpose, at the end of which a stage had been erected. M. Poincaré, the Minister, received most cordially his guests, who comprised, besides the members of the Institute, a large admixture of very different elements, among which political men were predominant. A very pleasant evening was provided by the singers and actors, among which were the best of the Opera and of the Théâtre Français, and by the excellent orchestra of the Opera.

On the next day (Thursday, 24th) a general meeting was held in the large hemicycle of the new Sorbonne, so splendidly decorated by the paintings of Puvis de Chavannes. The President of the French Republic was present with such Ministers as were not professionally detained at the Chambre des Députés, and after the overture of Méhul's Joseph-Méhul was the first composer who belonged to the Institute-three speeches were delivered. M. Ambroise Thomas began, and was short. M. Jules Simon came next, but, as his voice is weak, he could not possibly make himself heard in more than a small fraction of the hemicycle. M. Poincaré, the Minister of Public Instruction, spoke last, and very appropriately. This long ceremony ended with a fragment of Mors et Vita, of Gounod, played by the orchestra of the Opera.

In the morning a short reception took place at the Elysée, where the President of the Republic received the foreign members of the Institute. The foreign associates and correspondants, to the number of fifty-five, were presented to President Faure by the office-bearers of their respective Academies. The President welcomed them, and held a short conversation with each, and M. Gaston-Boissier presented him with three volumes containing the minutes of the Institute since its foundation.

In the evening a banquet took place at the Hôtel Continental; two hundred and fifty members were present. After two short "after-dinner" speeches by M. Ambroise Thomas and M. Poincaré, M. Max Müller, acting as spokesman for all the foreign members and associates, proposed the health of the Institute, "which, alone, remains unaltered and immovable in its renown and glory, while so many things have changed during this century," in very excellent terms. Most happily inspired was Lord Kelvin in his address. The very cordial and sympathetic expression which the Royal Society gave to its feelings in its address to the Institute, was received with much satisfaction, and the few words which closed the orator's speech went to the heart of all Frenchmen : "Personally, I cannot express how much I appreciate the great honour you have done me in electing me among the associates of the Institute. But I owe to France an even greater debt. She has been, truly, the alma mater of my scientific youth, and has inspired my admiration for the beauty of science, which during my whole life has kept me chained in her service. It was Laplace who initiated me into celestial mechanics, and a few years later the venerable Biot led me by the hand and introduced me to Regnault's laboratory. To Regnault and Liouville I shall eternally be grateful for their kindness towards me, and for the solid teaching they gave me, in 1849 , on experimental physics and mathematics. M. President of the Institute, gentlemen, I thank you with all my heart. From what I have said, you will understand why I consider with perfect gratefulness France as the alma mater of my scientific life." Lord Kelvin spoke with his heart as well as with his reason, and the great applause which followed his speech must have told him that he had made no nuistake in doing so.

The $25^{\text {th }}$ was devoted to an afternoon in the Theâtre Français ; the programme, to be sure, was of somewhat an austere character. The Cid, the École des Femmes, and the Femmes Savantes were exceedingly classical and sedate. . . . though, what might have been put in their place we could hardly decide, and classics were probably more suitable for an audience comprising a large number of foreigners than some modern play, where the finesses might have been a little too subtle and delicate. A very nobly-felt and worded poem by Sully Prudhomme-the most philosophical of French poets of the period - was read by Mounet-Sully, the doyen, the veteran of the French theatre. In the evening a reception was held at the Elysée by the President, who most graciously shook hands with the foreign members who had already been at the Elysée in the morning. The members of the Institute were all but lost in a crowd of political men, senators, deputies, officers, and functionaries who had been invited to meet them.

The last act was a visit to the magnificent residence of Chantilly, to the Duc d'Aumale. A special train left the Northern Railway Station at I I.I 5 a.m., carrying 239 members, and at Chantilly eleven large vehicles transported the whole assembly to the chateau, through part of the woods, the race-course, and the stables. The Duke, who had hardly recovered from an attack of gout, had to receive his guests sitting in a rolling-chair, and received them most cordially. Lord Kelvin and other members of the British contingent had some conversation with the Duke in English, and the afternoon was devoted to inspection of the residence itself, which has been splendidly enlarged and embellished by the present proprietor, and to the surrounding grounds. The whole of Chantilly and of its contents, as we have already said, has been bequeathed by the Duke to the Institute. This represents nearly $£ 2,000,000$, exactly $43,000, \infty 00$ francs. As the Institute owns already some $25,000,000$ francs $(£ 1, \infty \infty, \infty)$ ), at the death of the Duke the whole amount will be of some $70,000, \infty 00$ francs (under $£ 3, \infty 00, \infty 0)$. The whole Institute distributes over 725,000 francs in prizes each year.

And now the festivities are over, and most of the Institute's guests have gone back to their home or country - may their remembrances be pleasant. They have met some of their fellow-workers, and new friendships have been formed. Such meetings are profitable. While ill-feeling between nations are being daily suggested and excited by the incautious and ill-advised prose of a number of irresponsible men, it is well that occasionally the heads and lights of different countries should meet and mingle together. Knowing each other better, appreciating each other, united by a same bond to a same faith, they may, by their influence, help to further the advent of the reign of reason and goodwill. A great number of men, like Moses, have already expired in view of the Promised Land; and doubtless many more will do the same. The Promised Land seems very remote, and hardly "promised." But this is no reason for not doing what should be done, and international assemblies of the "best of the land" cannot fail to exert a useful influence.

HENRY DE VARIGNY.

This account of the fêtes would be incomplete if we did not give M. Jules Simon's discourse on the Institute, the delivery of which formed the central feature at the meeting in the Sorbonne. As M. Jules Simon is the foremost French orator, and his style is remarkable not only for its brilliancy but for its terseness, we give the whole oration as it was delivered.

NO. I 357 , VOL. 527 